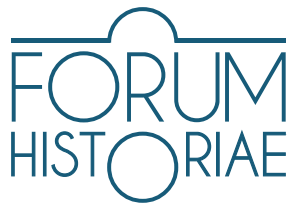

\title{
State of Grace: A Probe into Understanding Democratic Trust and Legitimacy Through the Eyes of the VPN (The Public Against Violence)
}

\author{
Matej Ivančík
}

\begin{abstract}
IVANČÍK, Matej. State of Grace: A Probe into Understanding Democratic Trust and Legitimacy Through the Eyes of the VPN (The Public Against Violence).

Gaining trust, both domestically and internationally, became a self-evident mission for the protagonists of the 1989 democratic revolution, something ever-present within the new policies aimed at a political and economic transition. This held true in particular with the Czechoslovak case. Unlike the situation in Poland or Hungary, where the legitimacy of the political transition was framed by the so-called Round Table Talks, revolutionaries from the Civic Forum (Občanské forum or OF) and the Public Against Violence (Verejnost' proti násiliu or VPN) had to extract their legitimacy directly from the very event of the Velvet Revolution. This exposed the policies of the OF and VPN to a participatory scrutiny of sorts in an even more imminent manner. In order to gain trust, at best transferable to actual political results, i.e. winning an election, the proponents of the democratic revolution in Czechoslovakia engaged in both policies and politics which would create an environment most preferable for their goals. This text focuses on the political language of ethics and politics, totalitarianism and Europeanization, focusing mainly on strategies used by the VPN and seeks to understand how an environment focused on developing and gaining trust functioned in the Slovak case.
\end{abstract}

Keywords: legitimacy, trust, political languages, ethics and politics, democratic revolution, Public against Violence, Verejnost' proti násiliu

DOI: https://doi.org/10.31577/forhist.2021.15.2.9

\section{Languages and Sources of Legitimacy and Trust: A Methodological Frame}

$\mathrm{W}$

Then it comes to ethics, politics, totalitarianism and the return-to-Europe narrative, one must question the motivation behind use of such concepts. Surely they are general notions subject to democratic debate, yet the use of these terms by certain actors within the particular post-socialist structure is, first and foremost, to be understood as a tool or frame through which emerging political actors would legitimize their actions, in this way gaining trust. ${ }^{1}$ This in turn allowed for promotion of a political and economic agenda, and at the same time, a challenge to political and ideological rivals. It would be a rather simplified understanding to view such a pursuit within a merely opportunist framework. Attempts at gaining trust and providing legitimacy played to

This work was supported by the Slovak Research and Development Agency under the Contract no. APVV18-0333.

1 The terms "trust" and "legitimacy" are used here with specific meanings. Legitimacy is not strictly understood as a legal term but rather refers to "justification". In the case of the protagonists of the 1989 democratic revolution, legitimacy was mainly drawn from the event of the revolution in the form of democratic participation of the people. Trust, on the other hand, is perceived as a more particular and rather political term. The VPN, as well as other groups, struggled for trust as a way to legitimize or justify their vision of the transformation of society. In other words, to form and retain legitimacy. 
the very core of the post-socialist understanding of what type of society the emerging elites would be willing to invest in. In the history of democracy, the central problem concerning legitimacy and trust lies in acknowledging the gap, or rather the dynamic, between the two respective concepts. During the "state of grace" as Pierre Rosanvallon describes the brief period following the elections, legitimacy and trust merged into one. ${ }^{2}$ Normally the gap between these two concepts is an inherent part of democracy according to Rosanvallon. ${ }^{3}$ Such a state can be observed in a well-functioning, liberal democracy and is in itself, an element which allows us to interpret democracy in a dynamic manner. The question then is: how is the period from the outbreak of the democratic revolution to the elections in June 1990 perceived in society? It is my belief that the event of revolution provided its protagonists with the same, if not higher, level of legitimacy than elections would have in a liberal democratic regime. ${ }^{4}$

Support for such a statement relies on several assumptions. Firstly, the main actors of the democratic revolution-former dissidents-disposed of "symbolic capital", which the revolution only bolstered. ${ }^{5}$ The idea behind this symbolic capital was one of a continuous and openly accentuated opposition to the Communist regime and the overwhelming presence of the party in both public and private life. When the Communist regime collapsed, as Jiří Suk revealed, the resulting power vacuum allowed the intellectuals to occupy a strategic position within a highly concentrated political space. ${ }^{6}$ Such a situation does not normally occur during typical power transitions in liberal-democratic regimes.

Secondly, the former dissidents, intellectuals and other democratic protagonists exploited a situation which could be described as adherence to the most radical solution within the existing political realm, i.e. not a democratisation of the Communist regime but a democratic revolution. As Suk continues, the perestroika Communists, or reformists, operated from a much weaker position. Moreover, a similar argument was made by James Krapfl, who highlighted that the initial participatory outburst in regions, factories, schools, administrative offices, etc., eventually yielded in favour of an umbrella brand, the VPN. ${ }^{7}$

Furthermore, the period after the revolution to the June 1990 election saw a range of political hopefuls attempt to make a run at the VPN candidate list. In the Slovak case, this held true not only for the former 1968 reform Communists, but also the Democratic Socialists party and the Movement for Civic Freedom. ${ }^{8}$ Yet the VPN movement's original success and political capital was also a strong reminder of its popular force, which became visible during the early period before the election. Although various actors sought to join the VPN, a great deal of individual adepts were refused. ${ }^{9}$ It can be suggested that those

2 ROSANVALLON, Pierre. Counter-Democracy: Politics in an Age of Distrust. Cambridge : Cambridge University Press, 2008, p. 4.

3 ROSANVALLON 2008, p. 4.

4 The role of democratic participation was reinforced through the unfolded absence of a stable institutional environment, caused to a major extent by the lack of a solid referential framework. This can be seen in the emergence of the role of parliament as well. GJURIČOVÁ, Adéla - ZAHRADNÍČEK, Tomáš. Návrat parlamentu: Češi a Slováci ve Federálním shromáždění 1989 - 1992. Praha : Argo - ÚSD AV ČR, 2018.

5 SUK, Jiří. Labyrintem revoluce: Aktéři, zápletky a křižovatky jedné politické krize. Praha : Prostor, 2020, p. 24.

6 SUK 2020, p. 24.

7 KRAPFL, James. Revolúcia s ludskou tvárou: Politika, kultúra a spoločenstvo v Československu po 17. Novembri 1989. Bratislava : Kalligram, 2009, pp. 232-264.

8 Slovak National Archive (SNA), Bratislava, Public Against Violence II. section (f. VPN II.)., inventory number (inv.) 108 , box (b.) 27 Secretariat.

9 SNA, f. VPN II., inv. 108, b. 27, Secretariat, Withdrawals and dismissals of candidates. 
rejected applicants provided a prospect pool for other subjects' electorate. This is just a hypothesis, however.

When examining the legitimacy of post-socialist societies through the lens of an intellectual history enquiry, both content as well as the form of politics and policies carried out by key performers in the transformation deserve equal attention. In other words, both content and form are to be considered political language. Contemporary debates on the legitimacy of democratic-mainly western-societies since the late 1980s culminated at the turn of the 1980s and ' 90 s. $^{10}$ In a way, post-socialist debates on democracy and democratisation can be understood as a mere continuation, or rather a by-product, of those western debates, which were heavily influenced by the relationship between morality and legality. When examined within a societal scope rather than merely a political one, we cannot differentiate between the two concepts. ${ }^{11}$ In other words, as Jürgen Habermas put it, conventionally externalized law and morality are mutually complementary. Within this respective understanding, significant for every modern society, the post-socialist regimes were left to build their legitimacy on the mutual harmonisation of legal transformational objectives and a morally defined political practice ${ }^{12}$. Naturally, the historical and territorial experience of the developments of former socialist societies are not taken into account in this theoretical model. Thus, it is yet to be understood how respective experience influenced the processes of gaining trust for political subjects, parties and movements within an actual historical realm-mainly the event of democratic revolution and subsequent change of the regime.

The post-socialist democratic legitimacy building process worked on levels of continuity and discontinuity. The latter is to be understood as a break from the previous regime, or rather, a denouncement. All of the major political forces active in the emergence of the post-socialist political landscape, including the Communists, attempted some form of renouncement of the previous political practices, making their case for establishing a renewed trust within the new political realm. Continuity, the main subject of this analysis, offers a more structured ground for polemics. While the concept of democratic legitimacy is quite well-established among the discourse on democracy, the approach of intellectual history deems it to be of value when examining post-socialist societies' engagement with the concept of democratic transformation, which is a rather longue dureé concept. In essence, the period between the democratic revolution and the parliamentary elections in June 1990 witnessed some major legal changes that should be taken as illustrations of the stages of democratisation. However, historically speaking, the protagonists of those changes were far from sure that the process was ever guaranteed to materialize. In this way, let us drift from this teleological interpretation and-not solely for the purposes of this paperput an emphasis instead on a particular political landscape within which subjects were actually driven to gain trust in order to legitimize the very notions they attempted to achieve.

10 BALL, Terrence - FARR, James - HANSON, Russell L. (eds.) Political Innovation and Conceptual Change. Cambridge : Cambridge University Press, 1989.; HUNTINGTON, Samuel. The Clash of Civilizations and the Remaking of World Order. New York : Simon \& Schuster, 1996.

11 HABERMAS, Jürgen. Diskursivní teorie liberální demokracie. Praha : Karolinum, 2018, p. 99.

12 The terminological non-interchangeability of morality/morals and ethics is fully acknowledged, nonetheless a fluid line has been drawn between these concepts here as within contemporary political discourse; it could hardly be defined in a precise manner. Though, such a blurred line could actually justify usage of the terms more broadly. 
Here, concepts of democratic legitimization and the acquisition of trust are understood as mutually entwined and inseparable.

According to Charles Tilly, democratisation understood as a partial integration of interpersonal trust networks into public politics entails a sort of twofold shift of trust. Firstly, "citizens trust the organization of consultation and protection sufficiently to wait out shortterm losses of advantage instead of turning immediately to non-governmental means of regaining lost advantages". ${ }^{13}$ This speaks exactly of the political void, an interregnum from the outbreak of the democratic revolution to the election in June 1990, which is actually recognised when analysing the mechanisms of democratic legitimisation and gaining trust. Tilly's concept of trust works on the combined principles of "bottom-up" and "top-down", stressing a necessary interaction between institutional framework and citizen participation. His second shift reinforces this principle, stating that "citizens build into risky, long-term enterprises the assumption that the government will endure and meet its commitments." ${ }^{14}$ Similarly, in agreement with the first statement, faith in the government's endurance and satisfactory-though, not necessarily successful-results of its policies requires a measurable amount of trust, usually exhibited in the form of repeated election or the absence of civil disobedience.

Placing the understanding of democratisation together with trust networks, Tilly's argument provides a more detailed and thus more suitable concept of the relationship between democracy and trust. ${ }^{15}$ This should be strongly underlined, as earlier transitological studies have suggested a rather essentialist connection between the two concepts. While one can agree with William Mishler and Richard Rose's claim that trust is particularly important for democratic governments because they cannot rely on coercion to the same extent as other regimes and because trust is essential to the representation relationship, it is far from settled to say, as they have, that:

In the post-Communist systems of Eastern and Central Europe, excessive trust is not a concern. The immediate problem is overcoming the abiding cynicism and distrust which are the predictable legacy of Communist rule. ${ }^{16}$

In an audacious manner, it can be maintained that there is no particular reason based on empirical evidence that would suggest a general distrust of the Communist system as such, or for that matter, claim the opposite about the democratic system other than that of support for the VPN's revolutionary programme. More likely, citizens could ascribe affiliation to either regime based on a feeling of representation or perhaps on the regime leadership's ability to fulfil their pursuit of welfare. It is not the purpose of this paper, however, to contend that higher levels of trust were cast towards democratic regimes. Eventually, trust was directly expressed in the initial requirements of democratic revolutionaries, such as eliminating the Communist party's monopoly and introducing political plurality and basic civil liberties. It should rather be expressed as an implication that the ahistorical, post-dissident interpretations, which automatically accompany democracy building along with the mass support of citizens, should be omitted. Instead, researchers should identify different sources

13 TILLY, Charles. Trust and Rule. In Theory and Society, 2004, Vol. 33, No. 1, pp. 20-22.

14 TILLY 2004, p. 22.

15 TILLY 2004, p. 22.

16 MISHLER, William - ROSE, Richard. Trust, Distrust and Skepticism: Popular Evaluations of Civil and Political Institutions in Post-Communist Societies. In The Journal of Politics, 1997, Vol. 59, No. 2, p. 419. 
of legitimisation of democratic transformation and trust amongst the post-socialist political actors in order to better understand the mechanisms and tools employed in attempts to gain political trust.

The aforementioned line of reasoning by Tilly emphasizes a restructuring of trust networks within the process of democratization. This approach suggests a dynamic period within which the structure of citizens' trust is being assigned to democratic institutions. This is why solely speaking of gaining support through an election process is insufficient. The question is: how can the subjects of this trust restructuring be analysed, and at the same time, from where did their legitimacy originate? Finally, once these matters are resolved, how did the source of such legitimacy influence the political environment within which the protagonists of democratic change materialised their policies and politics of gaining trust? In other words, what effect did the very nature of the democratic revolution have on its flag-bearers in terms of envisioning, contemplating and materializing their policies and politics of gaining trust?

Although a teleological understanding of the push towards an established democratic regime cannot be assumed, what actually can be observed quite clearly are the political languages ${ }^{17}$ employed by the Civic Forum and the Public Against Violence, notwithstanding other actors, articulated within the post-revolutionary discourse in which a focused endeavour towards democratization can be traced. For this matter, the concepts of morality or ethics and politics, totalitarianism and the return-to-Europe narrative, or Europeanisation, have been selected for analysis. More precisely, these will be examined as political languages utilized by VPN as political tools to legitimize the very actors employing them within the emerging political landscape. In doing so, they engaged in pursuing trust transferable to election gains. The aim of my analysis is twofold. First, focusing on the VPN's active employment and utilisation of particular policies. Second, drawing attention to the VPN's peculiar understanding of politics in terms of apolitical concepts-promoting moral values and ethics as primary guiding principles and denying the usefulness and legitimacy of institutionalised politics exercised through political parties and organisations. For this reason, both archival materials as well as the articles produced in the VPN's newspaper Verejnost' are examined, in addition to other media and publications.

When considering a study of political languages employed by the VPN, I must define how the landscape they were produced in was comprehended.

The most striking aspect of this environment is actually the realm created by the Czecho-Slovak democratic revolution in 1989. James Mark deems the imagery of the falling of the Berlin wall as a symbol that actually was not ingrained in the East-Central European collective

17 The concept of "political language" is understood here as it was formulated by intellectual historian from the Cambridge historiographical school of political thought or intellectual history John Pocock. Pocock considers political language as a form of discourse, a stable set of idioms or conventions that a historian should understand as source material, not a mere reflection of historical context. One should see political languages as existent within their multitude. Furthermore, the user and recipient of political language perceives historical reality through these societal denominators. They are thus a vital part of understanding the historical phenomena they represent. Moreover, such an approach allows us to observe a multitude of meanings within the respective political language since they can reflect more than one subject's interpretation of the historical situation. See RICHTER, Melvin. Reconstructing the History of Political Languages: Pocock, Skinner and the Geschichtliche Grundbegriffe. In History and Theory, 1990, Vol. 29, No. 1, pp. 38-70; POCOCK, John. Political Thought and History: Essays on Theory and Method. Cambridge : Cambridge University Press, 2009, cited in: KOPEČEK, Michal. Hledání ztraceného smyslu revoluce: Zrod a poćátky marxistického revizionizmu ve střední Evropè 1953-1960. Praha : Argo, 2009, pp. 32-34. 
remembrance due to the very nature of the "negotiated revolutions", mainly embraced by Poland and Hungary and to a considerably lesser extent by Czechoslovakia in later days as well. ${ }^{18}$ As Adam Michnik put it, the non-violent nature, the negotiations and the willingness to embrace the Round Table talks as part of the foundational myth were to be used in building the post-Communist system. ${ }^{19}$ In Czechoslovakia, however, Round Table talks would not occur until the outbreak of revolution on November 17, 1989, delivering a higher ground to the protestors. Within this understanding, the rather loosely institutionalized talks were more of a vehicle for the actual defeat of the regime. Though possibly a result of a mere chronological lag in outcome, it could be argued that such negotiations had in fact weaponized the collective action, creating a stronger potential for legitimacy.

Michal Kopeček highlights that the revolutions of 1989 in East-Central Europe were marked by a re-mythologized national pathos where historical changes were represented by a nationa ${ }^{20}$ struggle for liberation; the nation stood as one and swept away Communism. ${ }^{21}$ While this imagery might hold true for the East-Central Europe revolutions in general, it definitely bears importance in the case of Czechoslovakia. Here, people could actually see signs of democratic transformation as being unfurled directly by the respective actions of the population. ${ }^{22}$ James Krapfl claims that the most critical element of the Czechoslovak revolution was the aspect of participation..$^{23}$ Although, one can argue that if this were the case in the actual toppling of the Communist regime, there is an undeniable understanding of the people as subjects of the revolutionary movement, and therefore expected legitimacy.

Similarly, Jeffrey Isaac highlights the participatory aspect of the 1989 revolutions. ${ }^{24}$ Though he does not claim that personal investment played a considerably bigger role than the liberal transformations, he certainly attributes a relevance to the phenomenon of democratic participation. Isaac's interpretation is highly valuable here, since it draws attention to the dynamic between the two meanings of 1989.

To say the least, there is strong evidence that the participatory democratic imagination occurred as a dominant force that shaped the development of the Czechoslovak internal political realm. It is within this frame that we as researchers must investigate the variety of political languages that left their mark on the developments in Czechoslovakia after the 1989 revolution. This analysis offers a more long-term insight into the challenges, as well as their respective historical forms, that emerged as a result of the dynamic between the rather elitist, liberal understanding of the revolution and the more popular participatory one.

Pierre Rosanvallon's premise that citizenship is not merely a form of belonging but rather a form of social power ${ }^{25}$ properly captures the tone of the revolutionary outburst of 1989

18 MARK, James. The Unfinished Revolution. New Haven and London: Yale University Press, 2010, pp. 2-3.

19 MARK 2010, p. 2.

20 The expression "national" is not conceived in terms of ethno-nationalism, but rather in a more patriotic or com munitarian manner; as an adjective of a collective adherence to a certain idea of the past.

21 KOPEČEK, Michal. Human Rights Facing a National Past. In Geschichte und Geselschaft, 2012, Vol. 38, No. 4, p. 29.

22 It is in no way suggested that Poland or Hungary do not embody such cases. The situation in Czechoslovakia, however, brought a more dynamic shift from a substantially less liberalized environment, precisely thanks to popular pressure.

23 KRAPFL 2009, pp. 19-25.

24 ISAAC, Jeffrey C. The Meanings of 1989. In Social Research, 1996, Vol. 63, No. 2, p. 294.

25 ROSANVALLON, Pierre. Intellectual History and Democracy: An Interview with Pierre Rosanvallon. In Journal of History of Ideas, 2007, Vol. 68, No. 4, p. 706. 
Czechoslovakia. His thoughts strongly agree with Krapfl's well-documented emphasis on the democratic citizenry participatory aspect of the so-called Velvet Revolution as being considerably decisive. ${ }^{26}$ Even if it might be assumed that international, economic or political factors contributed substantially to the regime change, the social power, as Rosanvallon put it, which endured during and beyond the period of crowded squares, cannot be ignored.

Pierre Rosanvallon expounds upon his ideas into a system of understanding democracy in its complexity by maintaining the notion of a dynamic relationship between two kinds of distrust: liberal and democratic. ${ }^{27}$ Social power accumulated as a result of the democratic revolution could simply not disappear afterwards. Instead, it was dispersed into a variety of understandings of what the democratic change could mean for citizens and/or their political or cultural organizations. These understandings are traceable within the discourse articulated by the political languages of the time, as mentioned above. The VPN leadership, then, had to communicate political interests through, by or against the very political languages presented in the emerging political landscape of the Czecho-Slovak realm, the Slovak domain in particular.

\section{Form and Content of Gaining Trust in the VPN}

As stated in the introduction, not only actual policies but also the form, or rather the style, of politics of the VPN will be examined as a political language in itself. In this manner, the interwoven morality, ethics and politics is analysed, from both discussions and presentations of the VPN. Such an entwinement was built on the previous dissident discourses on human rights, politics and democracy.

The importance of the dynamics between morality, ethics and politics was mainly seen in lively internal debates, articles, exhibitions and even in the political programme objectives for the 1990 elections. Their purpose resided in creating a complementary, yet very active, instrument of persuasion mechanisms for gaining trust, hopefully transferable to electoral gain.

On 5-6 April, Bratislava castle held an exhibition combined with a conference, all under the banner of "Ethics and Politics. Art against Totalitarianism". The event was organized by the VPN with the Slovak Ministry of Culture, the Austrian Education and Research Ministry and the Austrian Institute for Humanities. It brought together a plethora of international figures, such as György Konrád, Adam Michnik, Péter Kende, Jacques Rupnik, Pavel Tigrid and many others, with local intelligentsia active within the VPN ranks such as Miroslav Kusý, Ladislav Snopko and Martin Bútora, among others. Most of the contributions dealt with the concept of the relationships between power, politics, democracy, ethics, morality, legality and the role of intellectuals in the transformation process. Regardless of the ubiquitous anti-totalitarian and anti-communist vocabulary employed by the vast majority of contributors, ${ }^{28}$ what immediately stands out is an ac-

26 KRAPFL 2009, pp. 19-25.

27 ROSANVALLON 2008, pp. 6-8.

28 HUDEK, Adam. Twenty Years Wasted? Constructing a Narrative of 1989 in Slovakia. In HUDEK, Adam et al. Overcoming the old borders: Beyond the Paradigm of Slovak National History. Bratislava : Institute of History, Slovak Academy of Sciences in Prodama, 2013, p. 170. 
centuated endeavour to justify the VPN style of politics as the righteous one. Consider the following statement by Miroslav Kusý:

For the very reason that we have experienced racism, nationalism, and socialism as political ideologies, we are now returning to such an understanding of politics, which positions it at the same level as public service-very similar to communal service. This does not mean de-honestation of politics, this is just a natural defence mechanism of the public. ${ }^{29}$

Péter Kende even defined their legitimacy through the relationship between ethics and politics. ${ }^{30}$ Anti-politics was an established style of practising politics and Slovakia was no exception. It should be acknowledged, though, that this intellectual phenomenon is a powerful tool in gaining trust. Within the post-dissident milieu, the understanding of Communism as a direct embodiment of party politics could be seen as something of a given. The remaining majority of the population, however, could have easily held differing views and instead of liberal democratic replacement, may have strived for a more direct participatory involvement.

It is no way suggested that the vision of the VPN directly and willingly fought democratic participation, nor should it be accused of at least plotting such a scheme. Internal debates as well as the subsequent political programme objectives of the VPN simply show its liking for anti-politics, moral politics or ethical pronouncements of politics and, at the same time, the VPN's willingness to transform these views in an actual political tool for gaining trust. This is very clearly demonstrated by a great deal of the reactions to the aforementioned symposium on ethics and politics. The Coordination Centre of the VPN dedicated quite a substantial internal discussion to such responses in which many aspects were tackled. For instance, Péter Kende's contribution was criticized by Lubomír Feldek for actually recognizing politics and ethics as two divergent concepts. ${ }^{31}$

Other examples of insisting on a peculiar interpretation of politics as an ethical public service are seen in the concept of "internal totalitarianism" as advocated by Adam Michnik, or as put by Martin Milan Šimečka, "totalitarianism in us". ${ }^{32}$ Consequently, the debate continued by tackling the issue of totalitarianism. Fedor Gál, a main protagonist in the VPN movement, suggested that people corrupted by totalitarianism are not totalitarianism themselves, their behaviour was merely a deteriorated reaction to the long-term frustration of unfulfilled needs. The implication of his opinion unfolded a sort of practical conclusion; "Every revolution consists of two phases: the struggle for victory and the struggle for power. The latter ought to be omitted." ${ }^{3}$ Instead of understanding this as a solely ethical position-however honest it may have been-such a worldview needs to be included within a general description of the VPN as a movement

29 KUSÝ, Miroslav. Etika a politika ako praktizovaná mravnost'. In Etika a politika: Umenie proti totalite. Bratislava : Slovenská národná galéria, 1990, p. 35.

30 KENDE, Péter. Cesta k slobodnému životu. In Etika a politika: Umenie proti toalite. Bratislava : Slovenská národná galéria, 1990 , pp. 28-29.

31 SNA, f. VPN II., inv. 117b, b. 33. Secretariat, 5 April 1990, minutes from the Ethics and Politics symposium. This divergence was, according to L'ubomír Feldek, mentioned in an informal discussion. It is clear from the document, though, that Feldek was not satisfied with such an interpretation.

32 SNA, f. VPN II., inv. 117b, b. 33, Secretariat, 5 April 1990, minutes from the Ethics and Politics symposium. Šimečka is mentioned in the document as Milan. It is, however, probably his son, Martin Milan Simečka.

33 SNA, f. VPN II., inv. 117b, b. 33, Secretariat, 5 April 1990, minutes from the Ethics and Politics symposium. 
that did not seek power as an end itself, but rather a means to achieve a certain desirable outcome beneficial for democratic transformation. Overall, Gál's very notion is informed by understanding politics through the lens of anti-politics. In addition, it is tempting to assume that the very fact the relationship between politics and ethics had been exposed as a matter for discussion could itself serve political purposes. Although, it also poses a question as to what extent this idea was reflected by the general public in the same manner. ${ }^{34}$

As for the results of the symposium, Martin Milan Šimečka came to the conclusion that it did not resolve the question of the interrelation of politics and ethics. However, the VPN's election programme objectives were already published and the document bore witness to both the ambiguity as well as intertwinement of politics and ethics. The movement explicitly promoted the term "new politics" (nové politikum), which encompassed the very relationship of the issues as embodied by the VPN's endeavours. The VPN dubbed itself a "movement which is, thanks to its ethos, new and unique and thus hard to define as a subject within our society." ${ }^{35}$ It struggled to pursue its civil society ethos, while at the same time aspiring to victory in the upcoming political contest. Essentially, its (un)pragmatic hesitancy to resolutely claim to be either a political or civil society subject reinforced the need to define itself as a "new politics" subject. As the programme stated, the movement "was born as a political necessity in the sense of an awakened citizenry." ${ }^{36}$

This constant need for justification has to be considered in a more excessive frame, though. Far from being a mere internal matter, it developed into a constitutive discourse with a direct political impact. The combination of the internal need to understand its own role on one hand, and the external environment of an ever more politically emergent arena on the other produced or reinforced new forms of languages loaded with ideological constructs, one being the label "totalitarianism". While acknowledging the term's usage drew legitimacy from late socialist dissident discourse, one must not exclude the differences in its post-socialist usage. Here, Adam Michnik's influence played a considerable role, as will be elaborated below. However, the post-1989 usage of totalitarianism as a political language must be perceived within an environment of liberal distrust ${ }^{37}$ as was posed by Pierre Rosanvallon. Simply put, the major shift resided in the fact that the former dissident discourse gained an upper hand precisely because of the democratic legitimacy acquired as a result of the regime change.

The Czechoslovak case, with an actual democratic participatory revolution-unlike the Hungarian or Polish instances - reinforced this aspect substantially. Thus, the period after November 1989 saw a population even more susceptible to democratic participation, and for that matter, its negation. The Slovak case in particular forced the VPN to

34 The newspapers of the VPN, Verejnost', wrote about the exhibition of April 10, though focusing mostly on the artistic aspect. LESNÁ, Luba. Proti totalite umenia. In Verejnost', 10 April 1990, p. 7.

35 SNA, f. VPN II., inv. 105, b. 24, Secretariat, Fedor Gál - "Predstava o krajine", 30 January 1990.

36 SNA, f. VPN II., inv. 105, b. 24, Secretariat, Fedor Gál - "Predstava o krajine", 30 January 1990.

37 KOPEČEK, Michal. From Narrating Dissidence to Post-Dissident Narratives of Democracy: Antitoalitarianism, Politics of Memory and Culture Wars in East-Central Europe 1970s-2000s. In BARŠA, Pavel - HESOVÁ, Zora - SLAČÁLEK, Ondřej (eds.) Central European Culture Wars: Beyond Post-Communism and Populism. Praha : Vydavatelství Filozofické fakulty Univerzity Karlovy, 2021, pp. 28-83. (In press. Cited with kind permission from the author). 
struggle for legitimacy against other forms of collective force, namely those employed by the ethno-nationalist imagination. Within this frame, VPN protagonists utilized the political language of anti-totalitarianism against subjects who bore the nationalist flag. Here, a term coined by Michal Kopeček, "usable totalitarianism", is wholly accurate. According to him, it means to emphasize the democratic credentials of the post-socialist regime-and its proponents (M. I.) - and foster a sense of belonging. ${ }^{38}$ This sense of belonging entwines with Rosanvallon's understanding of liberal distrust. The term's use, however, was subject to specific national contexts. The VPN employed it as tool against the ever more present nationalist discourse, attacking the "privatization" of the meaning of the revolution. On the other side, the situation in the Czech Republic used this style of discourse against the Communist threat, real or imagined. ${ }^{39}$ In Slovakia, a nationalist agenda had gradually emerged and the VPN protagonists acknowledged the political threat in its protraction, as articulated by the ever louder Slovak National Party (SNS) and organizations such as Matica slovenská and Štúrova spoločnost’.

The particular usage by the VPN is evidenced in various examples. What is most striking, however, is the attempt to interpret the democratic revolution itself through the language of usable totalitarianism. As Fedor Gál put it:

I am convinced that the credentials of civic initiatives in Czechoslovakia reside in the fact that they removed the fear of the Communist party's totalitarianism from people. [...] The speed with which, and many times the way itself in which the freed space became occupied, brought a new role the (civic - M.I.) initiatives have to face; to remove the fear from people themselves. Should they succeed, the free elections cannot turn out differently than in a victorious manner. The public will become the victor. ${ }^{40}$

Internal debates on the style of politics the VPN should employ continued throughout the months before the elections in June. The concept of totalitarianism-in-us was also articulated at the symposium Ethics and Politics by Adam Michnik: "Chauvinism represents a perverse response to the feeling of a lack of national identity. The biggest threat is not Communism or the Soviet Union, but rather ourselves". ${ }^{41}$ Robert Brier contends that Michnik's understanding of totalitarianism played a vital role in the term's transnational late socialist and post-socialist acceptance. ${ }^{42}$ Perhaps it can be assumed that through Havel and subsequently through such events as the Ethics and Politics symposium, it reached the broader Slovak intellectual milieu too. However, further research here is required. It is yet important to focus on the Slovak political environment where the notion of totalitarianism-in-us, could thrive. ${ }^{43}$

Moreover, usable totalitarianism came knocking when the VPN-and OF-had to deal with accusations of power-grabbing structures not substantially different from

38 KOPEČEK, Michal. Czech Republic: From the Politics of History to Memory as Political Language. In Cultures of History Forum, 02. December 2013, https://www.cultures-of-history.uni-jena.de/debates/from-the-politics-of-history-to-memory-as-political-language, DOI: 10.25626/0021.

39 KOPEČEK 2013.

40 SNA, f. VPN II., inv. 105, b. 24, Secretariat, Fedor Gál - "Vízia našej cesty", 16 January 1990.

41 SNA, f. VPN II., inv. 117b, b. 33. Secretariat, 4 April 1990, minutes from the Ethics and Politics symposium.

42 BRIER, Robert. Adam Michnik's Understanding of Totalitarianism and the West European Left: A Historical and Transnational Approach to Dissident Political Thought. In East European Politics and Societies, 2011, Vol. 25, No. 2, pp. 199-201.

43 Within this environment, Michnik's thought also played an important role in understanding national chauvinism as totalitarianism, an idea which particularly struck Martin Milan Šimečka. See, SNA, f. VPN II., inv. 117b, b. 33, Secretariat, 4 April 1990, minutes from the Ethics and Politics symposium. 
the Communists. The awareness of such a problem is supported by both an appeal to the movements' commitment to ethical principles, ${ }^{44}$ and later on, by simply condemning those who "stood in the way of transformation." ${ }^{45}$ Both attempts shared a common denominator; totalitarianism in us. In the former, Petr Pithart publicly denounced power-grabbing attempts within the OF and VPN ranks, mainly municipal and those within factories saying, "We have to defend against the totalitarianism - the one which stands against ourselves as well as the one which, I am not happy to say it, could stem from us." ${ }^{46}$ When assembling a list of candidates before the elections, this became a problem for the Coordination Centre of the VPN. They had to openly admit that not all the candidates fulfilled the requirements for the public image of the movement.

The VPN disposed of a guideline which provided essential recommendations and constraints which the candidates had to observe. ${ }^{47}$ Furthermore, the VPN's Coordination Committee struggled with its own internal democratic structure, which eventually pushed it into opting for an autonomous model for the selection of candidates. The definitive solution before the June 1990 elections favoured a method where the Coordination Committee suggested a candidate, usually a recognizable figure, and then the regional VPN representatives would approve them. ${ }^{48}$ In addition, the Coordination Committee was confronted by a number of civil letters directly denouncing particular VPN candidates. Often the objection had to do with a candidate's alleged Communist past, such as one from the town of Turčianske Teplice. ${ }^{49}$

Coordination Committee member Martin Milan Šimečka emphasized the high moral expectations VPN candidates had to meet. The majority of nominees should have consisted of politically and professionally moulded personalities who had lived up to the moral authority amassed during the fight against the totalitarian system, before or during the revolution. ${ }^{50}$ Such a wording provided operating space for even former Communists who happened to recognize either the righteousness or necessity of the democratic revolution. Needless to say, it allowed the VPN to promote a non-violent transition of power and include even former opponents if they expressed like-mindedness in the democratic transformation. ${ }^{51}$ The ambiguity of the VPN's indecision to become either a civil movement or a political party was also considered to be a political problem after the elections. There were two possible outcomes considered, either a loss of popularity or loss of principles. ${ }^{52}$ One must, however, perceive this dichotomy as an impasse of the very post-dissident intellectual understanding of the political development. In other words, it was all a result of the failure to resolve the internal debate on the interrelation of politics and ethics.

44 SNA, f. VPN II. oddelenie, inv. 105, b. 24, Petr Pithart - "Milí priatelia”, January 1990.

45 Civil initiative VPN, Častkovce, Trápi nás. In, Verejnost', 10 April 1990, p. 2. One of the results of the previous totalitarianism employed by the Communist regime was civil apathy. In combination with mistrust towards VPN protagonists, this was considered by the initiative as an obstacle on the way to a better society, "My God, people, get rid of the fear, open your gates to others, do not block our revolutionary road."

46 SNA, f. VPN II., inv. 117b, b. 33. Secretariat, Petr Pithart - "Milí priatelia", January, 1990.

47 SNA, f. VPN II., inv. 109, b. 28. Secretariat, A Candidate's Guide, 1990.

48 SNA, f. VPN II., inv. 103, b. 23. Secretariat, Minutes from the Political Club, 4 March 1990.

49 SNA, f. VPN II., inv. 108, b. 27. Secretariat, Letters, Turčianske Teplice, 26 May 1990.

50 SNA, f. VPN II., inv. 103, b. 23. Secretariat, Minutes from the Political Club, 9 March 1990.

51 The ubiquity of the Central European post-socialist anti-Communism present in Czech Republic, Poland or Hungary was rather marginal in Slovakia.

52 SNA, f. VPN II., inv. 105, b. 24. Secretariat, 26 July 1990, minutes. 
Fedor Gál even expressed doubts whether the VPN propaganda would work, acknowledging to a casual observer that some of the regional VPNs' rhetoric might remind them of techniques of the past stating, "Instead of attracting people, we will lose them. Instead of informing them, we will entice rage and emotions, aggressiveness." ${ }^{53}$ In addition, Gál poignantly expressed what might have been the root of the discrepancy between desirable outcomes and what some feared could turn into a failure of the democratic revolution; an alleged difference between local and national interests. According to him, the problem was visible in assembling the list of candidates for election. ${ }^{54} \mathrm{It}$ goes without saying that national interests were considered as being represented by the Coordination Centre..$^{55}$

Yet there were more lines of division which may have contributed to the future VPN's problems with securing trust, such as the constant need for balance between participation and more of a liberal institutional approach, and also, the issue of affirmed cooperation with the Czech Civic Forum. The former concern has been elaborated on in a theoretical manner, emphasizing the VPN's need to acknowledge the social forces that emerged by way of the democratic revolution. The appeal for democratic participation was reflected in official letters the VPN issued to its supporters. Besides a reference to the instalment of pluralism and freedom as common goals manifested in the revolution, a careful recognition of the participation element occurred:

Our activities have gradually expanded and we are attempting to preserve both energy and freedom of the November squares. [...] Our vision of the so-called "participative democracy" is based on belief that a truly free and successful society does not solely reside in freely elected parliaments but also in an everlasting opportunity for every citizen to participate in public affairs through various civic activities. ${ }^{56}$

This draft outlined by Coordination Committee chair Fedor Gál was restructured, however, and in its final form signed by all of the Committee members the expression "participative democracy" was replaced by a mere reference to "democracy."57

The very acknowledgment of the VPN's original source of legitimacy, however, persisted through the early months and traces could be found in future developments. A member of the VPN's Political Department, Soňa Szomolányi, stated that the legitimacy of the VPN lay in November 1989, when it began removal of the old Communist regime. ${ }^{58}$ By adhering to this very important idea, the VPN succumbed itself to a pressure which could not be simply withstood without substantial political losses. The legacy of the "energy and freedom of the November squares" became a matter of political struggle itself.

The latter issue, cooperation with the Civic Forum, needs to be contextualized within two realms. The first consists of the aforementioned balance between liberal and in-

53 SNA, f. VPN II., inv. 117b, b. 33. Secretariat, 18 April 1990, minutes.

54 SNA, f. VPN II., inv. 117b, b. 33. Secretariat, 18 April 1990, minutes.

55 Regional and national pursuits played a major role in the later development of the VPN. Vladimír Mečiar decided to gain favour of the regional VPN organizations, which further developed into a political contest with major consequences, some of which are still visible today.

56 SNA, f. VPN II., inv. 109, b. 28, A "thank you note" to supporters before the June 1990 elections.

57 SNA, f. VPN II., inv. 109, b. 28, A "thank you note" to supporters before the June 1990 elections.

58 SNA, f. VPN II., inv. 90, b. 20. Expert groups, SR VPN, Organizational building of the movement, 11 July 1991. 
stitutional approaches to post-socialist transformation, and the second had to do with particular Slovak experiences with the perception of its Czechoslovak history. Both played a key role in gaining trust. The VPN based its legitimacy on compliance with the Civic Forum's pursuit of liberal economic transformation, or market transformation. On one hand, the VPN's proclamation on cooperation ${ }^{59}$ could bode well within a broader public demand for change. On the other hand, it could also contribute to an understanding that the major societal changes would be informed by a central cooperation of sorts, thus weakening the national government and parliament.

Moreover, the proclaimed cooperation ought to go beyond election cooperation, "The alliance is not merely an alliance for the election, but rather an alliance for development of the co-habitation of the Czech and Slovak nations in the democratic federation." ${ }^{0}$ By bundling the broader issue of societal transformation with the need for Czecho-Slovak coexistence, the VPN exposed itself to an open field of confrontation on yet another level, best characterized through the discourse on Czechoslovakism, which had substantially impacted the political environment even beyond the June 1990 election. ${ }^{61}$ Norbert Kmet' suggests that the fight against Czechoslovakism was vital for Slovak post-Communist elites, especially those who could have been perceived as discredited by their past political activities. The peculiarity of the Slovak normalization period helped establish and promote new Slovak elites, who played a significant role in justifying the Communist regime. After the revolution, however, they did not simply fade away but instead strived for continuity within the new democratic environment, either in the VPN or other movements and parties. ${ }^{62}$ The VPN's strong emphasis on universally applicable principles eventually clashed with a great deal of the former Communist elites. They then further capitalized on the VPN's very bifurcation of the dynamics between participatory, national, regionally and communally based forms of democracy and the liberal institutional democracy, which ultimately prevailed within its upper echelons. The cost of such an internal dispute resulted in the establishment of the platform For a Democratic Slovakia (Za demokratické Slovensko, ZDS), which later fully broke away in the form of the Movement for Democratic Slovakia (Hnutie za demokratické Slovensko, HZDS).

In the above paragraphs, a demonstration of how the formal aspect of the VPN's political style could be understood as a particular political strategy to gain political trust was attempted. This alone, in a way, was examined as a political language, mainly represented by the concepts of the entanglement of politics and ethics and the practice of usable totalitarianism.

59 SNA, f. VPN II., inv. 141, b. 180, Proclamation of OF and VPN to citizens of Czech and Slovak Federative Republic, 3 June 1990, signed by Peter Tatár.

60 SNA, f. VPN II., inv. 141, b. 180, Proclamation of OF and VPN to citizens of Czech and Slovak Federative Republic, 3 June 1990, signed by Peter Tatár.

61 KMEŤ, Norbert. Problém čechoslovakizmu na Slovensku po Novembri 1989. In HUDEK, Adam - KOPEČEK, Michal - MERVART, Jan (eds.) Čecho/slovakismus, Praha : Ústav pro soudobé dějiny - Nakladatelství Lidové noviny, 2019, pp. 379-383.

62 KMEŤ 2019. On the differences in continuities of the elites in Czechia and Slovakia after the 1989 revolution, see: EYAL, Gil. The Origins of Postcommunist Elites: From Prague Spring to the Breakup of Czechoslovakia. Minneapolis : University of Minnesota Press, 2003. 
A second political language now explored as an analytical tool applied in analysis of the emerging political landscape in the Slovak part of Czechoslovakia and/or the Czech and Slovak Federative Republic is the discourse of "return-to-Europe" or Europeanisation.

Within more liberal attitudes, the idea of Europe represented an antidote to nationalism. It meant breaking down barriers, building bridges and above all, integration into the European body. Such language could appear in order to unite or even to water down potential conflicts. That was the case in a speech by Milan Čič, prime minister of Slovakia, three months before the elections addressing the conflicting parts of emerging quarrels between Slovaks and Hungarians in the southern part of Slovak territory. ${ }^{63}$ Very often the national narrative of the past mixed with the return-to-Europe vision, as expressed by Alexander Dubček, chair of the Federal assembly, at the commemoration of Milan Rastislav Štefánik. He voiced concern that the path to an integrated Europe should not be weakened, but on the contrary, it should be based on a mutual agreement of the two nations. Thus, it was within this particular return-to-Europe frame that he warned against misusing the legacy of Štefánik for separatist ambitions. ${ }^{64}$

Instead, an independent sub-category of the return-to-Europe narrative was built on constant references to European accession negotiations, and more broadly, articles on the "caring" features of European politicians and institutions. When Willy Brandt visited Prague and Bratislava, the idea of Germany on the way to reunification served as a model for Czechoslovakia. Furthermore, a strong argument in favour of the VPN pursuits of smooth integration at the expense of petty, ethno-national quarrels was offered in the example of Romania, whose instability was a constant reminder of the importance of conducting liberal reforms. ${ }^{65}$ Romania represented, at the very early stages of post-revolutionary development, a rather threatening example of what could happen to a country that was unable to present itself as willing to undertake necessary reforms in a non-violent manner.

More importantly, an agreement on the form of integration was borne in the minds of the liberal elites, partly because there was a hope-pronounced by foreign minister Jiří Dienstbier at Harvard - that the former Eastern bloc could use a sort of Marshall plan in order to avoid possible competition among respective states. ${ }^{66} \mathrm{~A}$ very practical and rather modern aspect of return-to-Europe was embodied by the attempts of Slovak major political parties and movements to become incorporated into respective European party structures. A vocal protagonist of such attempts was the Christian Democratic Movement, or $\mathrm{KDH}$. The movement very quickly engaged in narratives highlighting the legacy of Charlemagne and the idea of Christian Europe as the true Europe, thus strengthening their legitimacy.

The narrative of return-to-Europe could be perceived as embedded in a broader understanding of Europeanisation. ${ }^{67}$ In addition, Francis Fukuyama in his magisterial

63 Chceme žit' v bratstve, slobode a humanizme. In Smena, 6 March 1990, p. 2.

64 Štefánik nemôže byt' zástavou pre separatizmus. In Národná obroda, 15 May 1990, p. 3.

65 FRIEDMAN, Thomas L. Upheaval in the East: Diplomacy; East Bloc Trips Buoys Baker Yet Alerts Him to the Odds. In New York Times, 12 February 1990, p. 12. https://www.nytimes.com/1990/02/12/world/upheavaleast-diplomacy-east-bloc-trip-buoys-baker-yet-alerts-him-odds.html

66 Druhý Marshallov plan. In Národná obroda, 19 May 1990, p. 6.

67 MARK, James - IACOB, Bogdan C. - RUPPRECHT, Tobias - SPASKOVSKA, Ljubica. 1989: A Global History of Eastern Europe. Cambridge; New York : Cambridge University Press, 2019, pp. 129-130. 
work The End of History and the Last Man, stressed that for Eastern Europe, the year 1989 could have well meant an opportunity to be recognized. ${ }^{68}$ Such an interpretation tends to put the aforementioned myths of struggles for national liberation into a more complicated perspective, rendered considerably political. The idea that the radical contingency of an event brought by the revolution could pave the way for populations to demonstrate their pursuit to be recognized—take note of Rosanvallon's understanding of counter-democracy ${ }^{69}$-both internally and externally might have been perceived in a positive light.

Furthermore, Fukuyama also emphasized that there was no inherent contradiction between democracy and at least some of the newly emerging nationalisms. ${ }^{70}$ The Slovak/ Czecho-Slovak case adds credibility to this line of thinking. Therefore, one can be overwhelmed by vast amounts of articles, essays, declarations and statements that would connect the idea of return-to-Europe with a return to normalcy, civilization, democracy and decency. These, however, speak very little about what people could actually have imagined when they contemplated democracy, civilization, etc. The possible dynamic between recognition and liberal transformation has to be taken into consideration because gradually, out of these very dynamics, political splits could emerge.

The return-to-Europe vernacular could, at the same time serve, nationalist purposes, an idea best expressed by something one might call the German paradox. On one hand, the reunification of Germany could refer to the end of walls and borders between blocs, or more generally, between different mindsets. On the other hand, it could point to more sensitive national discourses and appear as a victorious struggle for national unity against all political and ideological odds. In other words, if Germans can be recognized as Germans, why not Slovaks? Multiplied by the wealth of changes occurring in Czechoslovakia and Slovakia respectively, this struggle between national recognition and liberal democratic aspirations was declared by Ján Cuper, who later ended up becoming one of the most loyal figures of the Mečiar regime. Regardless of his nationalist position, he voiced his concerns through a greatly symbolic case of the debate on the purpose of the new building for the Slovak parliament. While the VPN spread the idea that the new building could be a home for the intended Central European University, Cuper reacted, "I want every reasonable Slovak to understand my position. I am in no way against opening up to Europe. However, why does it again have to be at the expense of the nation?"71 The VPN retaliated within two days, publishing an article entitled Do we not want to be global? ${ }^{72}$

The universality, or rather polyvalence, of the return-to-Europe narrative allowed for political subjects to engage without necessarily contradicting their own worldviews. In doing so, they eventually contributed to a more or less vague imagination, thus rendering it a powerful political language. Consequently, this kind of political language needs to be examined within its dynamics and in relation to other political languages,

68 FUKUYAMA, Francis. The End of History and the Last Man. London : Penguin Random House, 2020, pp. $152-163$.

69 ROSANVALLON 2008, p. 8.

70 FUKUYAMA 2020, p. 37.

71 CUPER, Ján. Národný parlament na Bratislavskom hrade (Áno, či nie?). In Smena, 6 March 1990, p. 4.

72 GRESSNER, Juraj. Nechceme byt' svetoví? In Smena, 8 March 1990, p. 2. 
such as the aforementioned language of totalitarianism. The bottom line here is that the VPN could actually, like other subjects as well, employ the European narrative in order to gain trust. In other words, return-to-Europe represented a trump card for those in power to portray themselves as integrators. Indeed, a direct collaboration with the OF as well as with other international and foreign subjects or individuals could have served this very purpose as well.

\section{Conclusion}

The abovementioned political languages bore witness to attempts at gaining political trust and retaining or even reinforcing legitimacy gained through the event of a democratic revolution. The focus was on three particular yet interrelated political languages: the entanglement of ethics and politics, totalitarianism, and Europeanisation or return-to-Europe. In doing so, mainly the necessity of the historization of legitimacy and trust was accentuated. Relying on the theory of Pierre Rosanvallon, particularly his understanding of the gap between legitimacy and trust and more precisely, on the so-called state of grace where the two aspects tend to merge into one. However, attention should be drawn to the need to understand the examined political languages in their mutual existence as well as entwinement with other political languages, such as, memory politics, the language of decency, democracy, regional autonomy, etc. Above all, this paper accentuates the need to study trust and legitimacy not as sole political concepts, but rather as analytical tools which allow us to historicise the political imaginations and concepts employed by post-revolutionary protagonists within their activities and discourses. Put differently, a study of the attempts at gaining trust and the mechanisms of legitimacy helps us to extract practical political behaviour employed in the emergence of the political landscape of post-socialist societies because it reveals national peculiarities and explores them in the broader Central-European and European context.

Cite:

IVANČÍK, Matej. State of Grace: A Probe into Understanding Democratic Trust and Legitimacy Throughthe Eyes of the VPN (The Public Against Violence). In Forum Historiae, 2021, Vol. 15, No. 2, pp. 123-138. ISSN 1337-6861. DOI: https://doi.org/10.31577/forhist.2021.15.2.9

Matej Ivančík

Katedra všeobecných dejín

Filozofická fakulta Univerzity Komenského

Šafárikovo námestie 6

81499 Bratislava

email: matej.ivancik@uniba.sk 